\title{
Chemical Characteristics of Water Used for Cranberry Production
}

\author{
Eric $\mathrm{H}$ anson, ${ }^{1}$ \\ Carolyn D eM oranville, ${ }^{2}$ \\ Benjamin Little, ${ }^{3}$ \\ D avid M cArthur, ${ }^{4}$ \\ J acques Painchaud, ${ }^{5}$ \\ Kim Patten, ${ }^{6}$ Teryl Roper, 7 \\ Nicholi Vorsa, ${ }^{8}$ and \\ D avid Yarborough ${ }^{9}$
}

\begin{abstract}
AdDitional INDEX words. alkalinity, Vaccini um macrocarpon, water quality, sodium adsorption ratio, soluble salts
\end{abstract}

Summary. Since up to $2.4 \mathrm{~m}(8 \mathrm{ft})$ of water may be applied annually to cranberry beds for various production purposes, water quality can alter soil chemical properties and potentially affect plant health. M any cranberry plantings have recently been developed in nontraditional production regions and on atypical sites, where

The cost of publishing this paper was defrayed in part by the payment of page charges. U nder postal regulations, this paper therefore must be hereby marked advertisement solely to indicate this fact.

1Professor, D epartment of $\mathrm{H}$ orticulture, $\mathrm{M}$ ichigan State U niversity, East L ansing, M I 48824 (to whom reprint requests should be addressed; e-mail address: hansone@msu.edu).

${ }^{2}$ Assistant professor, $U$ niversity of $M$ assachusetts $C$ ranberry Experiment Station, PO Box 569, East Wareham, M A 02538.

${ }^{3}$ Cran Chile, Casilla 44, Lanco, Chile.

${ }^{4}$ R esearch associate, $D$ epartment of $P$ lant Science, 2357 $M$ ain $M$ all, $U$ niversity of B ritish C olumbia, $V$ ancouver, B.C. V6T 124 .

${ }^{5}$ Conseiller Regional en Horticulture, M.A.P.A.Q., 460 , blvd L ouis-Frechette, 2nd floor N icolet, Q uebec, Canada, J3T 1 Y 2.

${ }^{6}$ Associateprofessor, Washington StateU niversity L ong Beach Research and Extension U nit, 2907 Pioneer Road, Long Beach, WA 98631.

${ }^{7}$ Associate professor, Department of $\mathrm{H}$ orticulture, $U$ niversity of Wisconsin- $M$ adison, $1575 \mathrm{~L}$ inden $\mathrm{D}$ rive M adison, WI 53706.

${ }^{8}$ Professor, Rutgers U niversity Blueberry/ C ranberry Research and Extension Center, C hatsworth, N J 08019.

${ }^{9} \mathrm{~A}$ sso ciate professor, $\mathrm{U}$ niversity of $\mathrm{M}$ aine, $5722 \mathrm{D}$ eering $\mathrm{H}$ all, O rono, ME 04469-5722. 
chemical properties of the available water may differ from those in cranberry sites in the traditional production regions. Water currently being used for cranberry production was sampled from farms in most major production regions to characterize its chemical characteristics. $\mathbf{H}$ igh alkalinity in many samples was a concern, since alkalinity can increase soil pH above the desired level for cranberries. T otal soluble salt concentrations and sodium adsorption ratios were seldom high enough to be of concern. Water samples from longestablished plantings were lower in alkalinity, pH , and soluble salt concentrations than samples from newer plantings without production histories.

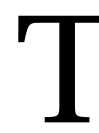
he quality of irrigation water is particularly important in cranberry (Vaccinium macrocarpon Ait.) production since up to $2.4 \mathrm{~m}$ ( $8 \mathrm{ft}$ ) of water may be applied annually (Sandler, 1997). Water is applied with sprinkler irrigation systems or by flooding, when the plants are submerged for protection from winter weather or for water harvesting. The water quality parameters most often of concern in crop production are 1) total salt concentration as measured by electrical conductivity, 2) concentration of sodium ( $\mathrm{N}$ a) relative to other ions, 3) alkalinity, and 4) borate, fluoride, or other ions in concentrations that are phytotoxic. The detrimental effects of high salt concentrations resulting from salt water intrusion into coastal cranberry bedswas documented (Chandler and D eM oranville, 1959). Water alkalinity

T able 1. L ocations, sources and sample numbers, and sampling times and handling, for water samples collected from cranberry plantings.

\section{L ocation, sampling time and sample handling, and \\ sources \\ (sample numbers)}

British Columbia

September. Frozen from $3 \mathrm{~d}$ of collection until analysis.

Reservoirs in D elta (2), East and West Richmond (4), Fort Langley (2), Langley (1), and Pitt M eadows (2).

Chile

September. N onrefrigerated transit for 22 to 24 d before analysis.

Properties of Cran C hile near Valdevia (5).

\section{$M$ aine}

August. Frozen from $3 \mathrm{~d}$ of collection until analysis.

Adroscoggin County stream (1). Reservoirs in Kennebec (1), Lincoln (1), and Washington (11) Counties.

\section{$M$ assachusetts}

$\mathrm{M}$ arch to August. Frozen from $3 \mathrm{~d}$ of collection until analysis.

Plymouth County streams and rivers (20) and ponds and reservoirs (18). Barnstable County streams and rivers (6) and ponds (5).

\section{M ichigan}

August to O ctober. Frozen from $3 \mathrm{~d}$ of collection until analysis.

Reservoirs in Allegan (1), Cheboygan (1), Chipewa (1), O ttawa (1), and VanBuren (4) Counties.

N ew Jersey

July. Frozen from $3 \mathrm{~d}$ of collection until analysis

Atlantic C ounty stream (1). Burlington County streams and rivers (12), drain (1), and lake (1). Camden C ounty river (1). 0 cean C ounty streams and rivers (3).

Q uebec

August. N onrefrigerated transit for 3-5 d before analysis.

I rrigation canal (1), reservoirs (5), and rivers (2) near St-L ouis-de-Blandford. I rrigation canal (1) and reservoirs (2) near N otre-D amede-Lourdes.

Washington

$\mathrm{O}$ ctober to $\mathrm{N}$ ovember. N onrefrigerated transit for $4 \mathrm{~d}$ or frozen until analysis.

Reservoirs and ponds recharged with groundwater in Grayland (5), Long Beach (5), and N orth Beach (2).

Wisconsin

$M$ ay to August. N onrefrigerated transit for 3-5 d until analysis.

Various sources in Adams (1), Jackson (1) J uneau (2), Portage (1), Vilas (3), and Wood (13) counties. M onroe County ponds and reservoirs (3) and ditches (2). O neida C ounty ponds (2). 
refers to the presence of carbonates and other ions capable of neutralizing acids. The hazard from alkaline water was recognized several decadesago after the diversion of alkaline water into cranberry beds rendered a successful production areain Wisconsin nonprofitable (Stevens, 1946a; Stevens et al., 1940). Cranberries require acidic soils (optimum range 4.5 to 5.0 ), and alkaline water apparently increased soil pH beyond this range. Korcak (1989) suggested that acid-loving plants such as cranberries may be inhibited by high soil $\mathrm{pH}$ or the high calcium ( $\mathrm{Ca}$ ) levels usually present in these soils. Sincemost of the alkalinity in natural waters is contributed by Ca carbonate (Brocksen et al., 1993), the Ca present in alkaline water may also behazardousto cranberries. Extremely low carbonate (alkalinity) levels may increase the risk that oxygen deficiency will occur if plantsare flooded during warm sunny days (Stevens and Thompson, 1942).

U ntil recently, commercial cranberry culture had been practiced on acidichydric soilsin M assachusetts, $\mathrm{N}$ ew Jersey, O regon, Washington, Wisconsin, and the $C$ anadian province of British Columbia. Surveys in the 1940s indicated that water used on M assachusettscranberry plantings was very low in alkalinity [ 1 to $6 \mathrm{mg} \cdot \mathrm{L}^{-1}$ (ppm) bound $\mathrm{CO}_{2}$ ] and acidic to neutral in $\mathrm{pH}$, whereas water from Wisconsin operations was usually higher in alkalinity ( 5 to $80 \mathrm{mg} \cdot \mathrm{L}^{-1}$ bound $\mathrm{CO}_{2}$ ) and $\mathrm{pH}$
(Stevens, 1946b). Water from N ew J ersey cranberry farms was described as very low in alkalinity (Stevens et al., 1940).

Strong demand for cranberries in the early 1990s encouraged the establishment of cranberry plantings in new regions such as $M$ aine, $M$ ichigan, $M$ innesota, and $\mathrm{N}$ ew York in the $U$ nited States, the $C$ anadian Provinces of Q uebec, N ova Scotia, and N ew Brunswick, and in Chile and some Eastern European countries. Where the traditional acidic, hydric soils are limited or protected from development by land-use policies or regulations, new plantings have been built on upland sites (Roper and Planer, 1993). N ew plantings may represent more diverse soil and water characteristicsthan wereassociated with the traditional production sites. This survey was conducted to describe the range of chemical properties of water sources currently being used for cranberry production. Theinformation may be useful to individuals evaluating the potential of new sites and water sources for cranberry production.

\section{Materials and methods}

Samples were collected between $M$ arch and N ovember 1998, from the edge of streams and rivers above or below cranberry operations, and the surface of ponds, lakes and reservoirs that served aswater sourcesfor cranberries(T able1). Water was placed in highdensity polyethyleneorglass bottlesand sent to the M ichigan State U niversity Soil and Plant N utrient Laboratory for analysis. A nalyses included $\mathrm{Ca}, \mathrm{K}, \mathrm{M} \mathrm{g}$, and $\mathrm{Na}$ (atomic absorption/ emission), chloride(chlorideelectrode), total alkalinity expressed as $\mathrm{CaCO}_{3}$ equivalent (Alkalinity Test Kit, LeM ott Chemical Products Co., Chestertown, $\mathrm{Md}$.), soluble salts (conductivity cell) and $\mathrm{pH}$ (pH electrode). Thesodium adsorption ratio (SAR) was calculated as described by Wilcox and Durum (1967) as a measure of sodium hazard: $\mathrm{SAR}=\mathrm{N}$ al $\div((\mathrm{Ca}+\mathrm{M} \mathrm{g}) / 2)$, whereconcentrations are expressed as meq. $L^{-1}$.

Because the time between sampling and analysis varied, 15 samples were analyzed immediately after collection and again after 4 to 6 weeks of storage at $18{ }^{\circ} \mathrm{C}\left(64.4{ }^{\circ} \mathrm{F}\right)$. Selected samples represented a range in $\mathrm{pH}$ and alkalinity levels. A t test was used to compare water quality parameters before and after storage.

\section{Results and discussion}

Themean $\mathrm{pH}$ of water sampleswas lowest in N ew J ersey (5.2) and M assachusetts (6.1) and highest in M ichigan (7.7), Chile (7.4) and Washington (7.4) (Table 2). The range and mean $\mathrm{pH}$ levels for $M$ assachusetts (range, 4.0 to 6.9; mean, 6.1) and Wisconsin samples (range, 6.2 to 8.0; mean, 7.0) compare closely with values recorded by Stevens (1946b) over 50 years ago in M assachusetts (range, 4.2 to 7.5 ; mean, 6.1 ) and Wisconsin (range, 4.2 to 8.7; mean,

T able 2. Mean and range (in parentheses) of selected chemical properties of cranberry water samples.

\begin{tabular}{|c|c|c|c|c|c|c|c|c|c|c|}
\hline \multirow[b]{2}{*}{ Region } & \multirow{2}{*}{$\begin{array}{c}\text { Sample } \\
\text { no. }\end{array}$} & \multirow[b]{2}{*}{ pH } & \multirow{2}{*}{$\begin{array}{c}\text { Alkalinity } \\
\left(\mathrm{mg}^{\circ} \mathrm{L}^{-1} \mathrm{CaC} \mathrm{O}_{3}\right)\end{array}$} & \multicolumn{5}{|c|}{ Chemical } & \multirow{2}{*}{$\begin{array}{c}\text { Soluble salts } \\
\left(\mathrm{dS} \cdot \mathrm{m}^{-1}\right)\end{array}$} & \multirow[b]{2}{*}{ SAR $^{z}$} \\
\hline & & & & $\mathbf{K}$ & $\mathrm{Ca}$ & $\mathbf{M g}$ & $\mathrm{Na}$ & $\mathrm{CI}$ & & \\
\hline British Columbia & 11 & $\begin{array}{c}6.9 \\
(6.5-7.3)\end{array}$ & $\begin{array}{c}40 \\
(16-61)\end{array}$ & $\begin{array}{c}6 \\
(1-9)\end{array}$ & $\begin{array}{c}36 \\
(0-160)\end{array}$ & $\begin{array}{c}7 \\
(3-21)\end{array}$ & $\begin{array}{c}42 \\
(5-162)\end{array}$ & $\begin{array}{c}83 \\
(17-354)\end{array}$ & $\begin{array}{c}0.28 \\
(0.11-1.05)\end{array}$ & $\begin{array}{c}1.6 \\
(0.3-4.0)\end{array}$ \\
\hline Chile & 5 & $\begin{array}{c}7.4 \\
(7.2-7.9)\end{array}$ & $\begin{array}{c}26 \\
(17-32)\end{array}$ & $\begin{array}{c}2 \\
(1-3)\end{array}$ & $\begin{array}{c}27 \\
(21-32)\end{array}$ & $\begin{array}{c}2 \\
(0-2)\end{array}$ & $\begin{array}{c}5 \\
(5-7)\end{array}$ & $\begin{array}{c}13 \\
(5-19)\end{array}$ & $\begin{array}{c}0.05 \\
(0.02-0.07)\end{array}$ & $\begin{array}{c}0.3 \\
(0.2-0.3)\end{array}$ \\
\hline$M$ aine & 14 & $\begin{array}{c}7.0 \\
(5.3-7.4)\end{array}$ & $\begin{array}{c}31 \\
(17-56)\end{array}$ & $\begin{array}{c}2 \\
(0-6)\end{array}$ & $\begin{array}{c}11 \\
(0-40)\end{array}$ & $\begin{array}{c}1 \\
(0-9)\end{array}$ & $\begin{array}{c}10 \\
(5-24)\end{array}$ & $\begin{array}{c}14 \\
(3-48)\end{array}$ & $\begin{array}{c}0.13 \\
(0.03-0.34)\end{array}$ & $\begin{array}{c}0.9 \\
(0.3-1.2)\end{array}$ \\
\hline M assachusetts & 50 & $\begin{array}{c}6.1 \\
(4.0-6.9)\end{array}$ & $\begin{array}{c}18 \\
(9-44)\end{array}$ & $\begin{array}{c}1 \\
(1-4)\end{array}$ & $\begin{array}{c}16 \\
(9-67)\end{array}$ & $\begin{array}{c}2 \\
(0-3)\end{array}$ & $\begin{array}{c}12 \\
(0-46)\end{array}$ & $\begin{array}{c}21 \\
(0-80)\end{array}$ & $\begin{array}{c}0.12 \\
(0.05-0.34)\end{array}$ & $\begin{array}{c}0.7 \\
(0.0-1.8)\end{array}$ \\
\hline M ichigan & 8 & $\begin{array}{c}7.7 \\
(6.9-8.1)\end{array}$ & $\begin{array}{c}105 \\
(32-190)\end{array}$ & $\begin{array}{c}5 \\
(2-12)\end{array}$ & $\begin{array}{c}66 \\
(20-133)\end{array}$ & $\begin{array}{c}11 \\
(1-20)\end{array}$ & $\begin{array}{c}4 \\
(0-8)\end{array}$ & $\begin{array}{c}16 \\
(0-38)\end{array}$ & $\begin{array}{c}0.32 \\
(0.11-0.58)\end{array}$ & $\begin{array}{c}0.2 \\
(0.0-0.3)\end{array}$ \\
\hline N ew Jersey & 19 & $\begin{array}{c}5.2 \\
(4.5-7.1)\end{array}$ & $\begin{array}{c}14 \\
(8-40)\end{array}$ & $\begin{array}{c}0 \\
(0-2)\end{array}$ & $\begin{array}{c}2 \\
(0-18)\end{array}$ & $\begin{array}{c}0 \\
(0-1)\end{array}$ & $\begin{array}{c}6 \\
(4-13)\end{array}$ & $\begin{array}{c}6 \\
(2-22)\end{array}$ & $\begin{array}{c}0.05 \\
(0.03-0.12)\end{array}$ & $\begin{array}{c}0.1 \\
(0.0-1.6)\end{array}$ \\
\hline Q uebec & 11 & $\begin{array}{c}7.0 \\
(4.9-7.6)\end{array}$ & $\begin{array}{c}46 \\
(16-116)\end{array}$ & $\begin{array}{c}4 \\
(0-15)\end{array}$ & $\begin{array}{c}34 \\
(10-57)\end{array}$ & $\begin{array}{c}1 \\
(0-3)\end{array}$ & $\begin{array}{c}0 \\
(0-0)\end{array}$ & $\begin{array}{c}0 \\
(0-0)\end{array}$ & $\begin{array}{c}0.15 \\
(0.02-0.31)\end{array}$ & $\begin{array}{c}0.0 \\
(0.0-0.0)\end{array}$ \\
\hline Washington & 12 & $\begin{array}{c}7.4 \\
(6.8-7.9)\end{array}$ & $\begin{array}{c}53 \\
(18-116)\end{array}$ & $\begin{array}{c}3 \\
(1-6)\end{array}$ & $\begin{array}{c}10 \\
(0-50)\end{array}$ & $\begin{array}{c}5 \\
(0-14)\end{array}$ & $\begin{array}{c}18 \\
(4-49)\end{array}$ & $\begin{array}{c}36 \\
(14-80)\end{array}$ & $\begin{array}{c}0.20 \\
(0.07-0.33)\end{array}$ & $\begin{array}{c}0.8 \\
(0.0-1.9)\end{array}$ \\
\hline Wisconsin & 28 & $\begin{array}{c}7.0 \\
(6.2-8.0)\end{array}$ & $\begin{array}{c}40 \\
(16-128)\end{array}$ & $\begin{array}{c}2 \\
(1-7)\end{array}$ & $\begin{array}{c}15 \\
(0-0-80)\end{array}$ & $\begin{array}{c}3 \\
(1-20)\end{array}$ & $\begin{array}{c}10 \\
(2-69)\end{array}$ & $\begin{array}{c}22 \\
(3-126)\end{array}$ & $\begin{array}{c}0.14 \\
(0.02-0.46)\end{array}$ & $\begin{array}{c}0.8 \\
(0.0-2.1)\end{array}$ \\
\hline
\end{tabular}

zSAR is the sodium adsorption ratio. 


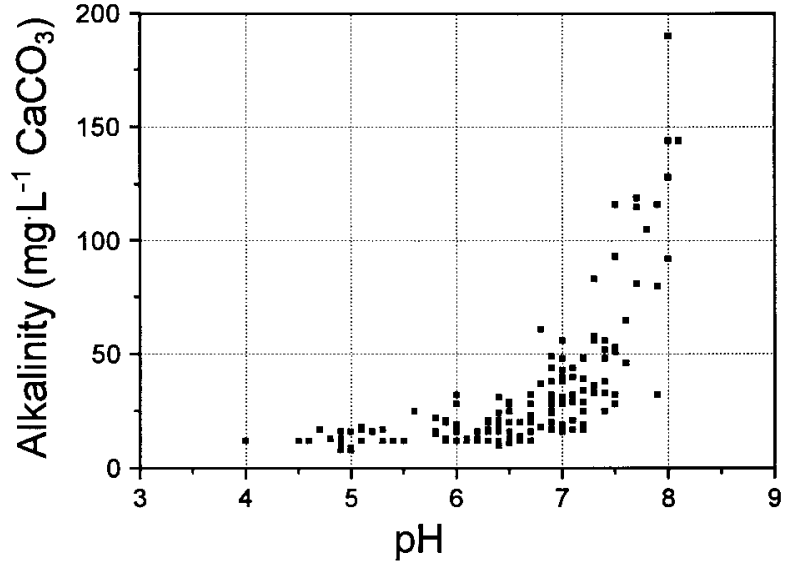

Fig. 1. R elationship between the pH and alkalinity levels of water samples collected from various cranberry production regions.

6.4). M ean alkalinity levels were lowest in $\mathrm{N}$ ew Jersey $\left(14 \mathrm{mg} \cdot \mathrm{L}^{-1} \mathrm{CaCO}_{2}\right.$ equivalent) and M assachusetts (18), and highest in Michigan (105). In previous surveys, water from Wisconsin cran berries exhibited a higher mean alkalinity, and a wider range, than water from $M$ assachusetts plantings (Stevens, 1946b), but a direct comparison with data in this study is difficult because the conversion of the alkalinity units used earlier (bound carbon dioxide) to the units used in our study is not clear.

The primary problem with the use of alkaline irrigation water is that soil pH may be increased above desired levels (H ull and Stevens, 1944; $H$ anson and Stein, 1999), resulting in increased weed competition and re- duced berry production (Stevens, 1946b). H owever, suitable water alkalinity and $\mathrm{pH}$ levels for cranberry production are not established. Based on observationsin M assachusetts and Wisconsin, Stevens et al. (1940) advised against cranberry production where water $\mathrm{pH}$ is above 7.0. Thisrule needs to bequalified when considering water from more diverse geographic regions, since several samples in this survey with a pH above 7.0 contained relatively low alkalinity levels (Fig. 1).

Water alkalinity levels are more significant than $\mathrm{pH}$, since it is alkalinity, not water $\mathrm{pH}$, that affects soil pH (Argo and Biernbaum, 1996). Growers can conveniently monitor water $\mathrm{pH}$ with moderately priced $\mathrm{pH}$ meters, or measure alkalinity with inexpensivetest kits. Alkalinity levels were consistently low $\left(<50 \mathrm{mg} \cdot \mathrm{L}^{-1} \mathrm{CaCO}_{3}\right.$ ) when $\mathrm{pH}$ was below 6.8, but varied from 20 to 180 $\mathrm{mg} \cdot \mathrm{L}^{-1}$ when $\mathrm{pH}$ wasabove 7.0 (Fig. 1). These data indicate that reasonably low alkalinity levels ( $<50 \mathrm{mg} \cdot \mathrm{L}^{-1}$ ) can be expected if $\mathrm{pH}$ is below neutral, but a $\mathrm{pH}$ above 7.0 isnot areliable predictor of alkalinity levels. It should be cautioned that the $\mathrm{pH}$ of surface waters is more variable over time than alkalinity, and may change as much as two units between years (Stevens et al., 1940)

The hazard associated with alka- line water may depend partly on management practices and soil characteristics. Water alkalinity is expected to have a greater effect on soil $\mathrm{pH}$ when high irrigation rates are applied to sandy soils with low buffering capacities. Sulfur and, to a lesser extent, aluminum sulfate and sulfuric acid are commonly used today to lower soil $\mathrm{pH}$, and can theoretically be used to counteract the effects of alkaline water on soil pH. It is not clear whether acidifying agents were used in an attempt to maintain proper $\mathrm{pH}$ levels in bedsadversely affected by alkal inewater (Stevens et al., 1940). A useful rule of thumb in estimating acidification requirementsisthat an acre-foot or 1,234 $\mathrm{m}^{3}(326,000 \mathrm{gal})$ of water with an alkalinity level of $100 \mathrm{mg} \cdot \mathrm{L}^{-1} \mathrm{CaCO}_{3}$ contains the equivalent of about 123 $\mathrm{kg}(270 \mathrm{lb})$ of lime. About $39 \mathrm{~kg}(86$ lb) sulfur or $68 \mathrm{~L}$ (18 gal) of concentrated sulfuric acid would beneeded to neutralize $123 \mathrm{~kg}(270 \mathrm{lb})$ of lime. Since up to $2.4 \mathrm{~m}$ of water may be applied annually to cranberries, acidification agents can represent a significant annual production cost where water alkalinity is high.

The amount of acidification required to counteract the effects of alkaline water may also depend on the bed design and water management. The majority of flood water applied for harvesting and winter protection often is removed by surface drainage and does not percolate through the soil. Thiswater would likely have less effect on soil pH than water that percolates into the soil, such as that applied as

T able 3 . E ffect of storage for 4 to 6 weeks on chemical characteristics of selected cranberry water sources.

\begin{tabular}{|c|c|c|c|c|c|c|c|c|c|}
\hline \multirow[b]{2}{*}{ G roup } & \multirow[b]{2}{*}{ Stored } & \multirow[b]{2}{*}{ pH } & \multirow{2}{*}{$\begin{array}{c}\text { Soluble } \\
\text { salts } \\
\left(\mathrm{dS} \cdot \mathrm{m}^{-1}\right)\end{array}$} & \multicolumn{5}{|c|}{ C hemical $\left(\mathrm{mg} \cdot \mathrm{L}^{-1}\right)$} & \multirow{2}{*}{$\begin{array}{c}\text { Alkalinity } \\
\left(\mathrm{mg}^{-\mathrm{L}^{-1}} \mathrm{CaC} \mathrm{O}_{3}\right)\end{array}$} \\
\hline & & & & $K$ & $\mathrm{Ca}$ & $\mathbf{M g}$ & $\mathrm{Na}$ & $\mathrm{Cl}$ & \\
\hline \multicolumn{10}{|l|}{ A cidic samples $(n=8)$} \\
\hline & No & 6.81 & 0.12 & 2.3 & 14 & 1.3 & 10 & 25 & 27 \\
\hline & Yes & 6.74 & 0.14 & 2.8 & 25 & 2.5 & 10 & 28 & 29 \\
\hline \multicolumn{10}{|c|}{ Alkaline samples ( $n=7)$} \\
\hline & Yes & 7.51 & 0.35 & 2.7 & 44 & 11.4 & 17 & 52 & 87 \\
\hline \multicolumn{10}{|l|}{ All samples $(n=15)$} \\
\hline & No & 7.23 & 0.20 & 2.5 & 27 & 4.7 & 14 & 30 & 57 \\
\hline & Yes & 7.10 & 0.24 & 2.7 & 34 & 6.7 & 13 & 39 & 56 \\
\hline \multicolumn{10}{|l|}{ Effect of storage } \\
\hline Acidic samples & & NS & NS & NS & NS & NS & NS & NS & NS \\
\hline
\end{tabular}

$\overline{N s, *}$ N onsignificant or significant $\mathrm{F}$ value at $\mathrm{P}<0.05$. 
sprinkler irrigation during the growing season. Flood water may have a greater effect on soil pH in beds designed with subsurface drains only. L ess acidifying agents may be needed if cranberry systems are designed to capture and reuse drain water. Water alkalinity levels were reduced when water percolated through acidic soils or if water had been treated directly with acid before application ( $\mathrm{H}$ anson and Stein, 1999).

Total soluble salt levels ranged from 0.02 to $1.05 \mathrm{dS} \cdot \mathrm{m}^{-1}$ (Table 2). The salinity hazard of irrigation water is classified as low for most crops if the soluble salt content is $<0.25 \mathrm{dS} \cdot \mathrm{m}^{-1}$, and levels above $0.75 \mathrm{dS} \cdot \mathrm{m}^{-1}$ are considered to present ahigh hazard (Wilcox and D urum, 1967). Of the 158 total samples, 142 contained soluble salt levels below $0.25 \mathrm{dS} \cdot \mathrm{m}^{-1}$ (low salinity hazard). O nly two samples had total salt levels considered to be potentially limiting for crop growth, and these came from British Columbia. These samples had soluble salt levels of 0.81 and $1.05 \mathrm{dS} \cdot \mathrm{m}^{-1}$, and also contained relatively high levels of $\mathrm{Na}(138,192$ $\mathrm{mg} \cdot \mathrm{L}^{-1}$ ) and $\mathrm{Cl}\left(323,354 \mathrm{mg} \cdot \mathrm{L}^{-1}\right)$. These samples were collected at the end of an abnormally dry summer, and the high $\mathrm{Na}$ and $\mathrm{Cl}$ levels likely resulted from a temporary intrusion of sea water into the irrigation supplies.

Based on general agricultural irrigation standards (Wilcox and D urum, 1967), the sodium hazard was found to be low in all samples, as indicated by the $\mathrm{N}$ a concentration and the sodium adsorption ratio (SAR) (T able 2). Sodium hazard is a function of the SAR and total soluble salt levels. At the soluble salt levels in these samples, SAR values below about 5 would be considered safe for most crops. SAR values ranged from 0 to 4.0 , and the only samples with values above 2.1 werethe aforementioned samplesfrom British Columbia.

Sample handling and duration between collection and analysis varied in this survey. To test whether chemical properties changed if analysis was delayed, groups of low pH samples ( $\mathrm{n}$ $=8$ ) and high $\mathrm{pH}$ samples $(\mathrm{n}=7)$ were analyzed shortly after collection, and again after 4 to 6 weeks of storageat 18 ${ }^{\circ} \mathrm{C}$. The only parameter affected significantly by storage was soluble salts, which was increased (Table 3 ). This suggests that variations in the time between sampling and analysis would have little effect on analytical results. When analysis was delayed more than 14 days, samples were frozen.

Water quality characteristicsin this survey may have been affected by sampling dates (Table 1). Samples from each region were collected at different times, and those from some regions ( $M$ assachusetts) were collected over a period of as much as six months. The $\mathrm{pH}$ of Wisconsin lakesisknown to vary with time of year, whereas alkalinity levels are generally more stable (Birge and Juday, 1911). Precipitation patternslikely varied with region and time, and could have affected the chemical properties of surface waters.

The water sourcesassociated with recently developed cranberry plantings appear to reflect a wider range in some chemical properties than water from older production regions. A total of 104 samples were associated with older cranberry plantings with a history of more than 10 years of production, whereas 51 samples were associated with plantings developed within the last 10 years that have limited production histories. Samples associated with newer plantings included all those from $C$ hile, $M$ aine, and Q uebec were, and selected samples from B ritish Columbia (5 samples), M assachusetts (3), M ichigan (7), and Wisconsin (6). As a group, samples from newer plantings had a higher mean $\mathrm{pH}$ (7.2), soluble salts $\left(0.19 \mathrm{dS} \cdot \mathrm{m}^{-1}\right)$, and alkalinity $\left(50 \mathrm{mg} \cdot \mathrm{L}^{-1} \mathrm{CaCO}_{3}\right.$ ) than samples from established plantings $(\mathrm{pH} 6.3$, soluble salts $0.12 \mathrm{dS} \cdot \mathrm{m}^{-1}$, alkalinity 25 $\mathrm{mg} \cdot \mathrm{L}^{-1} \mathrm{CaCO}_{3}$ ).

\section{Conclusions}

Theresultsof thissurvey wereused to describe the range in chemical properties of water sourcescurrently used for cranberry production. Alkalinity wasthe only parameter that was frequently outside the accepted ideal range for cranberries. Alkalinity levels appeared to be high enough in many samplesto impact soil $\mathrm{pH}$, and require applications of acidifying materialsto maintain theacidic soil conditions required by cranberries. Few samples appeared to contain total solublesaltsor SAR valueshigh enough to impact plant health or production. Samples from older production areas with a history of successful production were generally lower in $\mathrm{pH}$, alkalinity, and soluble salts than those from recently developed plantings without a proven production record.

\section{Literature cited}

Argo, W.R. and J.A. Biernbaum. 1996. The effect of lime, irrigation-water so urce, and water-soluble fertilizer on the $\mathrm{pH}$ and macronutrient management of container root media with impatiens. J. Amer. Soc. H ort. Sci. 121:442-452.

Birge, E.A. and C. Juday. 1911. The inland lakes of Wisconsin. Wis. Geol. Nat. $\mathrm{H}$ ist. Serv. Bul. 22 (as cited in Stevens et al., 1940).

Brocksen, R.W., M.D. M arcus, and H. Olen. 1993. Practical guide to managing acidic surface waters and their fisheries. L ewis Publ., Boca Raton, Fla.

Chandler, F.B. and I.E. DeM oranville. 1959. The harmful effect of salt on cranberry bogs. U niv. M ass. Expt. Sta. M isc. Publ. 1007.

$H$ anson, E.J . and A. Stein. 1999. Effects of water use on the chemical characteristics of cranberry soils. J. Plant N utr. 22:427-434.

H ull, H.H. and N.E. Stevens. 1944. $\mathrm{Changesin} \mathrm{pH}$ and in base-exchange properties of cranberry soilsfoll owing the use of alkaline water. Soil Sci. 58:405-408.

Korcak, R.F. 1989. Variation in nutrient requirements of blueberries and other calcifuges. H ortScience 24:573-578.

Roper, T.R. and T.D. Planer. 1993. U pland cranberry plantings in Wisconsin, thoughtson creating the appropriateagronomic conditions. Cranberries $\mathrm{Mag}$. $57(7): 4,18$.

Sandler, H .A. (ed.). 1997. M assachusetts cranberry production guide an information guide. U niv. M ass. Cranberry Expt. Sta., E ast Wareham, M ass., Ext. Publ. SP127.

Stevens, N .E . 1946a. Further observations on alkaline flooding water in cranberry growing. Trans. Wisc. Acad. Sci. 36:395398.

Stevens, N.E. 1946b. Observations on flooding water used in cranberry culture. M ass. Expt. Sta. Bul. 433:37-48.

Stevens, N .E. and N .F. Thompson. 1942. Factors influencing injury to cranberry plants during flooding. T rans. Wisc. Acad. Sci. 34:73-81.

Stevens, N.E., L.M. Rogers, and H.F. Bain. 1940. Alkaline flooding water in cranberry growing. Trans. W isc. Acad. Sci. 32:351-360.

Wilcox, L.V., and W.H. Durum. 1967. Q uality of irrigation water, p. 104-122. In: R.M. H agan, H.R. H aise, and T.W. Edminster (eds.). I rrigation of agricultural lands. Amer. Soc. Agron. M onogr. 11. 